\title{
Sovereign Green Sukuk Indonesia Dalam Tinjauan Maqashid Shariah
}

\author{
Naily Rohmah ${ }^{1}$, Abd Rohim ${ }^{2}$, Sri Herianingrum ${ }^{3}$ \\ Universitas Airlangga ${ }^{13}$ \\ Insitut Tazkia Bogor ${ }^{2}$ \\ Email: nailyrohmah63@gmail.com, rohimFA92@gmail.com, sriheria@gmail.com \\ Diterima:Juli 2020; Dipublikasikan: Juli 2020
}

\begin{abstract}
ABSTRAK
Permasalahan lingkungan menjadi isu global. Semangat pemerintah Indonesia untuk menyelesaikan masalah lingkungan diantaranya dilakukan dengan menerbitkan green sukuk untuk membiayai proyek proyek green sector di Indonesia. Ada 5 green sector yang telah dibiayai melalui dana sovereign green sukuk Indonesia yaitu transportasi berkelanjutan, energi terbarukan, pengelolaan limbah untuk energi dan lainnya, pertanian berkelanjutan, dan ketahanan terhadap perubahan iklim untuk daerah yang sangat rentan dan sektor atau pengurangan risiko bencana. Penerbitan sovereign green sukuk spemerintah Indonesia untuk membiayai 5 green sector ini tidak hanya legal secara hukum fiqh syariah, tapi juga sudah sesuai dengan nilai nilai maqashid syariah dalam bingkai alkulliyah al-khamsah yaitu menjaga agama (hifdzu ad din), menjaga Jiwa (hifdzu an nafs), menjaga akal (hifdzu al aql), menjaga keturunan (hifdzu an nasl) dan menjaga harta (hifdzu al mal).
\end{abstract}

Kata Kunci: green sukuk, sovereign green sukuk, maqashid syariah, green sector, al-kulliyah alkhamsah

\begin{abstract}
Environmental problems become a global issue. The enthusiasm of the Indonesian government to solve environmental problems is carried out by issuing green sukuk to finance green sector projects in Indonesia. There are 5 green sectors that have been funded through Indonesia's sovereign green sukuk funds namely sustainable transportation, renewable energy, waste management for energy and others, sustainable agriculture, and resilience to climate change for highly vulnerable regions and sectors or disaster risk reduction. The issuance of the sovereign green sukuk of the Indonesian government to finance the 5 green sectors is not only legally sharia fiqh, but it is also in accordance with the values of sharia maqashid in the frame of al-kulliyah al-khamsah, namely protecting religion (hifdzu ad din), protecting the Soul (hifdzu) an nafs), guarding intellect (hifdzu al aql), guarding offspring (hifdzu an nasl) and protecting wealth (hifdzu al mal)
\end{abstract}

Keywords: green sukuk, sovereign green sukuk, maqashid syariah, green sector, al-kulliyah alkhamsah

\section{PENDAHULUAN}

Isu pembangunan berkelanjutan pada dasarnya bukanlah hal baru di Indonesia. Isu pembangunan berkelanjutan sudah masuk dalam visi dan misi pembangunan bangsa Indonesia sebagaimana tertuang dalam Rencana Pembangunan Jangka Panjang Nasional 2005-2025 (RPJPN) dan Rencana Pembangunan Jangka Menengah Nasional 2015-2019 (RPJMN). Dalam RPJPN tersebut disebutkan bahwa diantara arah pembangunan nasional adalah mewujudkan Indonesia yang asri dan lestari diantaranya dengan mendayagunakan sumber daya alam yang terbarukan dan mengelola sumber daya alam yang tidak terbarukan (RPJPN 2005-2025 hal; 70). Adapun dalam RPJMN 2015-2019 dijelaskan bahwa diantara agenda pemerintah dalam hal pembangunan adalah pembangunan lingkungan yang tercermin pada fokus mitigasi kepada perubahan iklim, konservasi sumberdaya alam dan perlindungan ekosistem serta keanekaragaman hayati disertai dengan adanya rumusan cara pencapaian (means of implementation) (RPJMN 2015-2019 hal: 16). Sedangkan di tingkat internasional, isu pembangunan berkelanjutan ini telah ditetapkan secara resmi oleh PBB pada saat menyelenggarakan sidang umum tanggal 25 September 2015 di New York. Aksi terhadap masalah perubahan iklim ditetapkan menjadi salah satu Agenda pembangunan berkelanjutan (Sustainable Developments Goals atau SDGs) tahun 2015-2030. Oleh karena itu, sebagai bentuk kontribusi aktif dalam mengatasi dampak perubahan iklim yang sudah terjadi di seluruh dunia, Indonesia menjadi salah satu dari tiga puluh negara yang menjadi anggota Open Working Group (OWG) on Sustainable Development Goals (SDG) (katadata.co.id). Selain itu, Indonesia juga aktif 
dan menjadi bagian anggota dalam Forum Tenaga Ahli (Expert Forum) penyusunan konsep pembiayaan pembangunan berkelanjutan.

Sehubungan dengan hal itu, sebagai wujud nyata atas komitmen mencapai pembangunan berkelanjutan, Kementrian Keuangan sejak 2015 telah menerapkan pemeriksaan anggaran iklim atau lingkungan untuk melacak pengeluaran terkait iklim dan lingkungan dalam anggaran nasional. Proses tersebut memungkinkan pemerintah untuk mendapatkan ide yang lebih akurat tentang kesenjangan dalam pembiayaan yang dibutuhkan untuk memenuhi target solusi perubahan iklim. Dengan begitu, pemerintah Indonesia bisa mengetahui bahwa proyek pengendalian perubahan iklim membutuhkan investasi tambahan yang signifikan. Salah satu contoh kesenjangan anggaran demi mewujudkan lingkungan yang ramah dan asri, uraian dalam Rencana Strategis Kementrian Lingkungan Hidup dan Kehutanan tahun 2015-2019 yang menyebutkan bahwa alokasi untuk program pengendalian perubahan iklim yaitu sebesar Rp. 905,9 Triliun. Sedangkan kebutuhan dalam perhitungan Rencana Strategis Direktoral Jendral Pengendalian Perubahan Iklim mencapai Rp. 2,223 Triliun, sehingga terjadi defisit alokasi anggaran sebesar Rp. 1,317 Triliun. (Ditjen PPI, 2015).

Sebagai solusi atas kesenjangan anggaran tersebut, Kementerian Keuangan mempertimbangkan untuk memanfaatkan kekuatan pasar obligasi hijau global untuk mempercepat transisi menuju ekonomi hijau dengan menerbitkan Green Sukuk Indonesia. Dan akhirnya, Pemerintah Republik Indonesia pada tahun 2018 berhasil menerbitkan instrument keuangan green sukuk yang berkonsentrasi pada pembiayaan proyek green sector untuk mengantisipasi perubahan iklim dan proyek ramah lingkungan di Indonesia seperti pembiayaan energi terbarukan, transportasi berkelanjutan dan mitigasi resiko dan bencana. Penerbitan green sukuk pada tahun 2018 tersebut meruapakan yang pertama kalinya dilakukan oleh negara di dunia dan berhasil meraup dana sebesar US\$ 1,25 miliar. Dan hingga saat ini, Pemerintah menjadikan Surat Berharga Negara Syariah (SBSN) khusus pembangunan proyek ramah lingkungan atau green sukuk menjadi andalan dalam instrument pembiayaan Syariah di Indonesia. (DJPPR, 2018). Sehubungan dengan green sukuk sebagai pembiayaan proyek ramah lingkungan, pembahasan serupa pernah dijadikan objek pembahasan dalam penelitian Morea \& Poggi, (2017) tentang masukan sebuah inovasi pembiayaan sektor energi angin di Italia agar menggunakan green sukuk sebagai sebuah inovasi pembiayaan investasi berkelanjutan di Italia.

Terkait hal di atas, kemunculan instrument keuangan syariah berupa green sukuk tentu sangat menggembirakan karena menggunakan akad akad yang sesuai syariah. Indonesia telah melakukan inovasi dan kreatifitas dengan menjadikan pembangunan proyek proyek hijau negara Indonesia menggunakan akad akad yang sesuai syariah. Sebagai komponen dalam ekonomi syariah, titik focus tidak hanya pada produk keuangan yang halal dan sesuai akad syariah, tapi harus mengandung manfaat dan maslahah bagi masyarakat Indonesia sesuai dengan konsep maqashid syariah. Green sukuk khususnya di Indonesia harus memperhatikan tujuan penerapan syariah dalam praktiknya atau yang lebih dikenal dengan maqashid syariah.

Maqashid syariah menggambarkan pandangan holistik Islam sebagai pedoman hidup bagi Islam individu dan masyarakat (Dusuki \& Abozaid, 2007), termasuk entitas bisnis (Abdullah, 2012). Dalam beberapa tahun terakhir, diskusi tentang maqashid syariah telah meningkat secara signifikan dalam ekonomi makro atau mikro. Penelitian ini mencoba menjadikan maqashid syariah sebagai pilihan mengukur praktik green sukuk Indonesia. Penelitian ini mencoba mengeksplorasi praktik green sukuk Indonesia melalui tinjauan maqashid syariah. Dengan begitu, bisa diketahui bahwa penerapan green sukuk di Indonesia betul betul sudah sesuai dengan prinsip dan nilai maqashid syariah.

\section{Maqashid Syariah}

\section{TINJAUAN PUSTAKA}

Sebelum memahami tentang maqasid syariah, akan dijelaskan maqashid syariah secara harfiah terlebih dahulu. Maqashid syariah berarti tujuan hukum. Menurut (Syatibi, 2018) maqashid dari kata qashada yang berarti tujuan. Tujuan atau hasilnya yang diharapkan dari perundangundangan. Maqashid Syariah telah secara langsung disebutkan dalam Al-Qur'an dan Sunnah atau disimpulkan oleh sejumlah ilmuwan. Semua hal mengatakan urgensi pemenuhan maslahah (jalb al masalih) dari semua manusia dan untuk menyelematkan dari bahasa (daf'u al mafasid). 
Secara terminologi, menurut (Al-Yubi, 2001) maqashid berarti makna-makna dan hikmahhikmah dan sejenisnya yang dikehendaki Allah dalam tiap syariat baik umum maupun khusus, untuk memastikan maslahat hambanya. Maksud dari 'makna' adalah sebab, maksud dan sifat. Sedangkan hikmah berarti sifat, sifat syariat islam yaitu mendapatkan maslahah. 'Dikendaki Allah dalam tiap syariat' dimaksudkan bahwa Allah SWT menginginkan dalam syariatnya. Arti dari 'baik umum dan khusus' adalah mencakup syariat umum yang berisi tentang dalil-dalil syariah dan khusus berisi hukum-hukum islam. Sedangkan makna dari 'guna memastikan maslahat hambanya' adalah bahwa apa yang disyariatkan Allah tidak lain untuk masalahat hambanya di dunia dan akhirat.

Istilah maqashid berasal dari kata arab yang berarti prinsip, tujuan, niat (kasri \& Ahmed, 2015). Di kombinasikan dengan istilah "Syariah", (Abdul Aziz dan Mohamad, 2013) mendefiniskan sebagai "tujuan dan sasaran untuk undang-undang aturan islam atau hanya tujuan hukum islam". Menurut (Syatibi, 2018) membagi maslahah tersebut menjadi tiga derajat berurutan dari kebutuhan manusia, yaitu: Dharruriyah, hajjiyah, dan tahsiniyyah

1. Dharuriyyah memegang derajat maslahah tertinggi karena manusia tidak dapat hidup tanpanya. Jika seseorang tidak terpenuhi tidak terpenuhi maslahah dharuriyyah-nya, maka akan terjadi kerusakan di dunia dan akhirat. Kadar kerusakan sesuai dengan maslahah dharuriyyah yang hilang. Maslahah dharurriyah dilakukan dengan menjaga agama, jiwa, keturunan, harta, dan akal. Contoh dari menjaga agama ialah mendirikan rukun iman dan islam

2. Maslahah setelah dharuriyyah adalah maslahah hajjiyah. Maslahah hajjiyyah merupakan masalah yang bersifat memudahkan, menghindarkn manusia dari kesulitan dan kesusahan. Namun, ketiadaan maslahah hajjiyyah tidak menyebabkan kerusakan di dunia maupun akhirat. Contoh dari maslahah hajjiyyah adalah rukhsah dalam ibadah, dan jual beli salam dalam muamalat

3. Maslahah tahsiniyyah ialah pelengkap atau penyempurna dari dua maqashid sebelumnya, meliputi adat kebiasaan dan akhlak mulia. Salah satu dari maslahah tahsiniyyah adalah larangan membunuh wanita dan anak kecil dalam peperangan.

Menurut (Ismail et al, 2014) berpendapat bahwa maslahah adalah konsep yang lebih baik untuk menjelaskan motif ekonomi dari prespektif ekonomi islam yang bagian dari tujuan syariah, sehingga semua kegiatan kegiatan produksi yang berdampak pada maslahah sangat penting bagi manusia. Maslahah dibangun dari niai-nilai yang tertanam dalam sistem dunia, khususnya dalam sistem ekonomi (Choudhury, 2014). Maka, ekplorasi kesejahteraan ditemukan dalam teori ekonomi, dimana ia dapat menggantikan istilah "kesejahteraan". Istilah "maslahah" mengacu pada pemenuhan kebutuhan manusia melalui kreativitas, dinamisme, dan fleksibilitas (Al-Mubarak \& Osmani, 2010). Sedangkan (Dusuki dan Abdullah, 2007) berpendapat bahwa maslahah sebagai manifestasi dari 'aqidah (akidah)', ibadah dan akhlak (moralitas dan etika) dalam ekonomi, bisns dan kegiatan dunia lainnya. Para ulama terdahulu menyepakati bahwa shariah diturunkan untuk membangun kemaslahatan manusia di dunia dan akhirat. Dan shariah diturunkan untuk dilaksanakan sesuai dengan maqashid-nya agar kehidupan yang adil dapat ditegakkan dan kesejahteraan sosial dapat diwujudkan. Menurut (Al-Rahman, 1983) kemaslahatan adalah sesuatu yang bermanfaat bagi manusia, yang dapat diraih oleh manusia dengan cara memperolehnya maupun dengan cara menghindarinya. Hakikat perintah dan larangan syara' pada dasarnya untuk mewujudkan tujuan syariah yang dikembalikan pada suatu kaidah yaitu jalb al-masalaih wa dar'u al-mafasid (merealisasikan kemaslahatan dan menolak kerusakan).

Maqashid syariah menaungi lima unsur penting, kelima unsur ini merupakan hal yang sangat fundamental dan mencakup secara menyeluruh kehidupan manusia sehingga sering disebut dengan al-kulliyah al-khamsah (5 aspek menyeluruh), sehingga kerusakan pada salah satu aspek saja akan menimbulkan implikasi negatif yang luar biasa (Asy-Syatibi,1997). Sehingga maqashid syariah memberi perhatian, perlindungan dan proteksi (hifz) lebih terhadap lima unsur tersebut, yaitu menjaga agama atau keyakinan (hifzud-din), menjaga jiwa (hifzun-nafs), menjaga keturunan (hifzunnasl), menjaga akal dan intelektual (hifzul-aql) dan menjaga harta atau properti (hifzul-mal). Imam asy-syatibi mempertegas bahwasannya proteksi (hifz) kelima aspek dengan fundamental ini harus dilakukan dengan pelaksanaan dan perlindungan, mengindari dan menghilangkan. 


\section{Sukuk}

Sukuk merupakan salah satu jenis instrument keuangan syariah dalam lingkup pasar modal. Perkembangan industri keuangan yang pesat membuat sukuk menjadi semakin populer. Biasanya sukuk dikenal dengan istilah obligasi syariah oleh masyarakat awam, namun istilah tersebut kurang tepat karena penerbitan sukuk merefleksikan bukti kepemilikan atas suatu asset bukan besaran sebuah utang. Sukuk adalah jamak dari kata sakk (instrument yang legal, tanda kepemilikan atau cek) adalah istilah Arab untuk suatu sertifikat kepercayaan pada investasi syariah, pada beberapa tahun terakhir sukuk menjadi popular pada pasar modal, sejak masa kejayaan islam pada abad ke-13, sakk disebut sebagai sumber cek (cheque) yang berkembang di Eropa, yang mana merepresentasikan suatu kontrak atau hak atas suatu hutang (Sulaiman, 2012). Sedangkan menurut Fatwa Dewan Syariah Nasional (DSN) mendefiniskan sukuk sebagai suatu surat berharga jangka panjang yang berdasarkan prinsip syariah yang dikeluarkan emiten, untuk membayar pendapatan kepada pemegang obligasi Syariah berupa bagi hasil, margin dan fee, serta membayar kembali dana obligasi pada saat jatuh tempo (DSN-MUI, 2002). Sukuk adalah pembiayaan atau pinjaman terstruktur dari pemegang sukuk kepada penerbit sukuk. konsep umum penetapan harga sukuk mirip dengan obligasi. sukuk adalah menggunakan nilai waktu uang di mana nilai sekarang adalah harga sukuk sementara sukuk akan ditebus pada nilai masa depan atau nilai nominal pada saat jatuh tempo dan menghasilkan pendapatan (Razak, 2018). Namun pertumbuhan pasar modal Islam sebagai salah satu struktur dalam sistem keuangan islam telah mengamati penggunaan istilah dalam konteks yang lebih spesifik namun beragam. Keragaman penerapan sukuk di zaman modern dapat ditelusuri melalui definisi diatas.

Dengan kata lain yang lebih sederhana, sukuk adalah surat berharga jangka panjang yang dikeluarkan oleh Lembaga corporate atau pemerintah guna mendapatkan pendanaan atas proyekproyek tertentu yang di biayai. Surat tersebut diterbitkan dengan menggunakan prinsip-prinsip yang sesuai dengan Syariah sehingga terhindar dari hal-hal yang diharamkan Syariah dalam bermuamalah. Seperti mengandung unsur riba, gharar, maisir, dan lain-lain. Berdasarkan Sukuk Negara, sukuk dijelaskan sebagai suatu sertifikat bernilai sama yang mempresentasikan bukti kepemilikan pemegang sukuk (investor) atas suatu bagian tertentu dan tidak terbagi terhadap aset yang menjadi dasar penerbitan (underlying asset). Adanya kepemilikan investor atas underlying asset dalam sukuk, maka investor juga berhak memperoleh keuntungan yang dihasilkan dari transaksi atas aset tersebut. Keuntungan yang dimaksud dapat berupa bagi hasil, margin, uang sewa, atau fee yang telah disepakati sesuai akad yang digunakan pada awal penerbitan sukuk.

\section{Green Sukuk}

Beberapa tahun terakhir, telah diterbitkan sebuah produk pembiayaan dengan mempertimbangkan kembali sistem subsidi, dan alat pembiayaan memperluas pemeriksaan beragam model sosial dan keuangan yang telah ada dari sisi ekonomi Islam yaitu green sukuk. Green Sukuk merupakan sebuah terobosan instrumen keuangan yang diajukan sesuai syariat Islam sebagai respon terhadap perkembangan ekonomi hijau yang kian pasti (Morea, 2017). Penerbitan Green Sukuk pertama kali dilakukan oleh Security Commisionaris (SC). Malaysia melalui Sustainable and Responsible Investment (SRI) Sukuk pada 2015. Pasar sukuk global yang tumbuh cepat sangat cocok untuk menyalurkan modal di wilayah keuangan islam yang di kembangkan di pantai barat untuk energi terbaru dalam proyek ramah lingkungan. Sukuk adalah instrument keuangan Syariah yang dapat diperdagangkan yang dapat dikeluarkan baik oleh pemerintah maupun perusahaan untuk mengumpulkan dana dalam membiayai proyek-proyek pembangunan infrastruktur besar. Sukuk mirip dengan obligasi konvensional tetapi yang memiliki fitur yang konsisten dengan prinsip Syariah terkait dengan perbankan dan keuangan islam. Salah satu fitur yang menarik dari sukuk adalah memberikan hak kepemilikan pemegang asset dasar atau pendapatan dari asset tersebut. Penerbitan sukuk, misalnya telah memetakan tingkat pertumbuhan tahunan gabungan sebesar 44,0\% antara 2004 dan 2011 (IFSB, 2013).

Dana hasil penjualan green sukuk ini nantinya akan dialokasikan untuk membiayai proyekproyek yang masuk dalam kategori green sector yang telah ditentukan. Berdasarkan panduan dari pemerintah Indonesia, beberapa proyek yang dikategorikan green di antaranya: efisiensi energi dan renewable energy green building green tourism, disaster risk education, sustainable transport, waste to energy dan waste management, suistanable management natural resources serta sustainable 
agriculture. Selain menunjukkan komitmen pemerintah, green sukuk ini merupakan instrument yang memberikan dukungan Indonesia terhadap perluasan pasar green bond dan green sukuk baik domestik maupun internasional khusunya di Kawasan Asia Tenggara. Karenanya, Indonesia bangga terhadap upaya-upaya yang telah dilakukan menuju transisi pembangunan rendah karbon.

\section{HASIL DAN PEMBAHASAN}

\section{Sovereign Global Green Sukuk Indonesia}

Permasalahan iklim yang menjadi isu global membutuhkan kemauan dan komitmen politik yang kuat di masing masing negara untuk menyelesaikan permasalahan tersebut. Untuk hal itu, sebagai bentuk komitmen Indonesia ditingkat global maupun nasional, pemerintah Indonesia berhasil menerbitkan sovereign global green sukuk pada Maret 2018 dengan dengan total penyerapan dana US\$1,25 miliar atau setara dengan 16,75 T dengan kurs rupiah 13.400. Penerbitan ini didaulat sebagai sovereign green sukuk pertama di dunia dengan investor yang tersebar di seluruh dunia yaitu: $32 \%$ pasar islam, 25\% pasar Asia, 15\% EU, 18\% AS, dan 10\% Indonesia.

Berkat hal itu, Pada hari Selasa, 26 Februari 2019, Pemerintah Republik Indonesia menerima penghargaan internasional "Islamic Issue of the Year" dan "SRI Capital Market Issue of the Year" dari International Financing Review Asia di Hong Kong. Penghargaan ini diberikan atas keberhasilan Pemerintah menerbitkan Sukuk Negara di pasar internasional senilai USD3 miliar dan sekaligus keberhasilan menerbitkan Sukuk Negara di pasar internasional untuk membiayai proyek-proyek ramah lingkungan senilai USD1,25 miliar pada tanggal 1 Maret 2018 (djppr.kemenkeu.go.id).

Kesuksesan Indonesia sebagai penerbit sovereign global green sukuk pertama di Dunia tidak hanya berhenti pada 2018 saja, tahun berikutnya pada tahun 2019, Indonesia kembali menerbitkan sovereign global green sukuk kedua pada februari 2019 dengan nilai sebesar US $\$ 750$ juta atau senilai 10,05 triliun dengan tenor tenor 5,5 tahun dan imbal hasil (yield) sebesar 3,900\%. Dan terakhir, Indonesia menerbitkan green sukuk ritel pada November 2019 dengan penerimaan sebesar 1,45 triliun dengan tenor 2 tahun dan imbalan 6,75\% (floating with floor). Peneribitan green sukuk ritel ini menunjukan kepercayaan masyarakat global maupun masyarakat Indonesia dalam program pembiayaan program program ramah lingkungan dalam menjaga pembangunan yang berkelanjutan. Dengan begitu, total penerimaan Indonesia dari green sukuk sejak maret 2018 sampai November 2019 senilai 28,259 Triliun. Berikut diagram penerimaan Indonesia dari penerbitan green sukuk selama 2018-2019:

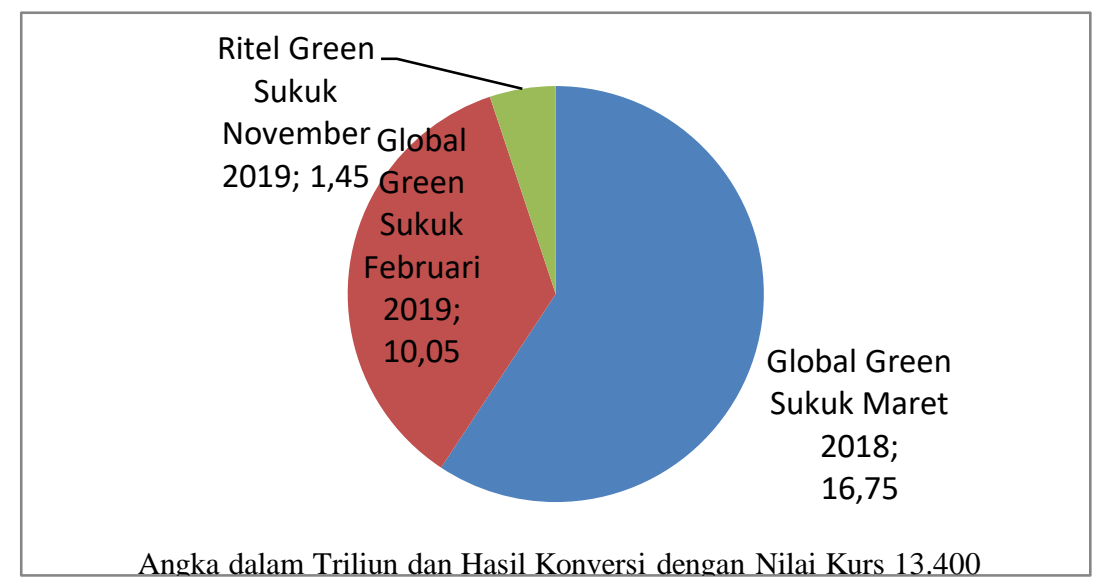

\section{Gambar 1. Total Green Sukuk Indonesia 28.259.880.000.000}

Sehubungan dengan penerimaan dana green sukuk tersebut, Pemerintah Indonesia melalui kementrian keuangan telah menerbitkan report penggunaan dana green sukuk senilai 16,75 Triliun yang diterbitkan pada Maret 2018. Dalam laporannya, kementrian keuangan menyebutkan bahwa dana dari penerbitan green sukuk Maret 2018 dialokasikan kepada berbagai program ramah lingkungan tahun 2016 dan 2018 untuk menunjang pembangunan berkelanjutan di beberapa kementrian. 
Kementrian yang menerima dana global green sukuk Maret 2018 untuk pembangunan proyek ramah lingkungan dan berkelanjutan terdapat pada 5 kementrian yaitu Kementrian Pekerjaan Umum dan Perumahan Rakyat (PUPR) untuk penggunaan re-financing proyek tahun 2016 sebesar 1,44 triliun dan proyek tahun 2018 sebesar 7,24 triliun. Kementrian perhubungan dengan penggunaan untuk re-financing proyek tahun 2016 sebesar 7 triliun dan proyek tahun 2018 sebesar 962,8 miliar. Kementrian pertanian untuk proyek pembangunan tahun 2018 sebesar 441 juta dan terakhir kementrian energy dan sumber daya mineral untuk re-financing proyek tahun 2016 sebesar 102,9 miliar. Adapun total biaya proyek hijau dan ramah lingkungan baik refinancing proyek tahun 2016 atau proyek 2018 dari 5 kemetrian tersebut menghabiskan dana dari green sukuk maret 2018 sebesar 16,75 triliun, rinciannya 8,5 triliun untuk refinancing proyek hijau dan ramah lingkungan 2016 dan 8,2 triliun untuk proyek hijau dan ramah lingkungan tahun 2018. Berikut rincian penggunaan dana di masing masing kementrian:

Tabel 1. Penggunaan Dana Hasil Penerbitan Green sukuk Maret 2018

\begin{tabular}{|c|c|c|c|}
\hline Kementrian/Lembaga & Nilai Provek 2016 & $\frac{\text { Nilai Provek }}{2018}$ & $\frac{\text { Total Nilai }}{\text { Provek }}$ \\
\hline $\begin{array}{l}\text { Kementrian Pekerjaan } \\
\text { Umum }\end{array}$ & 1.442 .361 .056 .874 & $\begin{array}{l}7.244 .253 .113 .40 \\
0\end{array}$ & $\begin{array}{l}8.686 .614 .170 .27 \\
\quad 4\end{array}$ \\
\hline $\begin{array}{l}\text { \& Perumahan Rakyat } \\
\text { Kementrian Perhubungan }\end{array}$ & 7.002 .478 .802 .535 & 962.832 .354 .300 & $\begin{array}{l}7.965 .311 .156 .83 \\
5\end{array}$ \\
\hline Kementrian Pertanian & 0 & 441.000 .000 & 441.000 .000 \\
\hline $\begin{array}{l}\text { Kementrian Energi } \\
\text { \& SUmber Daya Mineral }\end{array}$ & 102.953.668.111 & 0 & 102.953.668.111 \\
\hline Total & 8.207.526.467.700 & $\begin{array}{l}\text { 8.547.793.527.52 } \\
\quad 0\end{array}$ & $\begin{array}{l}16.755 .319 .995 .2 \\
20\end{array}$ \\
\hline
\end{tabular}

Sedangkan untuk green sector yang dibiayai oleh dana green sukuk maret 2018 terdapat 337 proyek hijau dan ramah lingkungan yang tersebar di beberapa sector. Setidaknya ada 5 green sector yang menjadi konsen pemerintah dalam proses pembangunan berkelanjutan dengan menciptakan proyek hijau dan ramah lingkungan. Jumlah Proyek terbanyak yang menggunakan dana green sukuk adalah sektor Ketahanan Daerah/Sektor Rentan Risiko \& Bencana dengan jumlah 241 proyek dengan biaya 7,19 triliun.

Proyek ini menelan biaya banyak karena memang beberapa wilayah di Indonesia tergolong rentan resiko dan bencana alam, sehingga dibutuhkan pembangunan proyek berkelanjutan untuk mewujudkan keberlangsungan di wilayah yang rentan resiko dan bencana. Urutan kedua adalah sector transportasi yang berkelanjutan dengan jumlah 57 proyek dengan biaya 7,96 triliun dan proyek tersebut tersebar di beberapa wilayah di Indonesia. Green sector berikutnya adalah sector pengolahan limbah menjadi energi dan lainnya sebanyak 26 proyek dengan biaya 1,37 triliun. Keempat adalah green sector pertanian yang berkelanjutan yang berjumlah 8 proyek dengan biaya sebesar 119,1 miliar dan terakhir energy terbarukan yang berjumlah 5 proyek dengan biaya 102,9 miliar. Dianatara proyek ini adalah pembangunan panel bertenaga surya yang sedang digalakkan di beberapa wilayah Indonesia.

\section{Praktik Green Sukuk Indonesia dalam Tinjauan Maqashid Syariah}

Pembahasan tentang maqashid shariah harus dimulai dengan pemahaman tentang maslahah atau manfaat publik. Keberadaan konsep maqashid shariah adalah menciptakan maslahah untuk semua manusia (Sirat et al, 2016). Dengan begitu, kajian tentang green sukuk dalam tinjauan maqashid shariah sangat penting karena green sukuk mulai banyak diterbitkan di negara-negara muslim dan non-muslim. Oleh karenanya, penerapan green sukuk khususnya di Indonesia harus memperhatikan tujuan penerapan syariah dalam praktiknya. 
Tabel 2. Penggunaan Dana Hasil Penerbitan Green sukuk Maret 2018

\begin{tabular}{|l|c|l|c|c|l|c|}
\hline Green Sector & $\begin{array}{l}\text { Juml } \\
\text { ah } \\
\text { Proye } \\
\text { k } \\
\mathbf{2 0 1 6}\end{array}$ & $\begin{array}{l}\text { Nilai Proyek } \\
\mathbf{2 0 1 6}\end{array}$ & $\begin{array}{l}\text { Jumla } \\
\text { h } \\
\text { Proye } \\
\text { k } \\
\mathbf{2 0 1 8}\end{array}$ & $\begin{array}{l}\text { Nilai } \\
\text { Proyek } \\
\mathbf{2 0 1 8}\end{array}$ & $\begin{array}{l}\text { Total Nilai } \\
\text { Proyek }\end{array}$ & $\begin{array}{l}\text { Total } \\
\text { Jumlah } \\
\text { Proyek }\end{array}$ \\
\hline Energi Terbarukan & 5 & $\begin{array}{l}102.953 .668 . \\
111\end{array}$ & 0 & 0 & $\begin{array}{l}102.953 .668 . \\
111\end{array}$ & 5 \\
\hline $\begin{array}{l}\text { Ketahanan Daerah/ } \\
\text { Sektor Rentan Risiko } \\
\text { \& Bencana }\end{array}$ & 50 & $\begin{array}{l}64.698 .469 .0 \\
28\end{array}$ & 191 & $\begin{array}{l}7.125 .543 .101 \\
.700\end{array}$ & $\begin{array}{l}7.190 .241 .57 \\
0.728\end{array}$ & 241 \\
\hline $\begin{array}{l}\text { Transportasi yang } \\
\text { Berkelanjutan }\end{array}$ & 39 & $\begin{array}{l}7.002 .478 .80 \\
2.535\end{array}$ & 18 & $\begin{array}{l}962.832 .354 .3 \\
00\end{array}$ & $\begin{array}{l}7.965 .311 .15 \\
6.835\end{array}$ & 57 \\
\hline $\begin{array}{l}\text { Pengolahan Limbah } \\
\text { Menjadi Energi \& } \\
\text { Lainnya }\end{array}$ & 26 & $\begin{array}{l}1.377 .662 .58 \\
7.846\end{array}$ & 0 & 0 & 1.377 .662 .58 & 26 \\
\hline $\begin{array}{l}\text { pertanian yang } \\
\text { berkelanjutan }\end{array}$ & 0 & 0 & 8 & 119.151 .011 .7 & $\begin{array}{l}119.151 .011 . \\
700\end{array}$ & 8 \\
\hline Total & 120 & $\begin{array}{l}5.547 .793 .52 \\
7.520\end{array}$ & 217 & $\begin{array}{l}8.207 .526 .467 \\
.700\end{array}$ & $\begin{array}{l}16.755 .319 .9 \\
95.220\end{array}$ & 337 \\
\hline
\end{tabular}

Tidak hanya sebatas legal dalam syariah saja, tapi harus mengakomodir maslahah dan manfaatnya untuk masyarakat Indonesia sebagai akktualisasi dari konsep maqashid shariah. Proyek proyek yang menggunakan dana green sukuk Indonesia harus betul betul berdampak maslahah kepada masyaralat. Dalam konteks Indonesia, Proyek yang didanai oleh penerbitan green sukuk 2018 jatuh ke dalam lima dari sembilan sektor hijau yang memenuhi syarat dalam kerangka kerja Indonesia untuk Green sukuk yaitu: transportasi berkelanjutan, energi terbarukan, pengelolaan limbah untuk energi dan limbah, efisiensi energi dan ketahanan terhadap perubahan Iklim untuk daerah yang sangat rentan dan sektor / Pengurangan Risiko Bencana .Penerimaan digunakan untuk membiayai proyek yang diselesaikan dari anggaran 2016 (51\%) dan untuk membiayai proyek baru dari anggaran 2018 (49\%) (DJPPR Kemenkeu,2019). Kelima green sector tersebut menjadi wujud nyata langkah pemerintah untuk menjaga lingkungan/environment (hifz al-bi'ah) di tengah perubahan iklim demi mencapai pembangunan yang berkelanjutan.

Sehubungan dengan itu, untuk menganalisis praktik sovereign green sukuk Indonesia dalam tinjauan maqashid syariah, dibutuhkan barometer khusus mengenai maqashid syariah untuk melihat praktik sovereign green sukuk Indonesia. Dalam hal ini, penelitian ini menggunakan lima unsur maqashid syariah atau yang disebut dengan al-kulliyah al-khamsah (5 aspek yang menyeluruh) hasil rumusan Imam Asy-Syatibi untuk menilai praktek penggunaan dana sovereign green sukuk yang telah beralangsung di Indonesia. Hal ini menjadi sangat fundamental karena telah mencakup secara menyeluruh segala aspek kehidupan manusia sehingga kerusakan pada salah satu aspek saja akan menimbulkan implikasi negatif yang luar biasa (Laluddin et al, 2012). Bagan berikut menggambarkan tentang maqashid shariah:

Kajian tentang sovereign green sukuk Indonesia dalam tinjauan perspektif maqashid shariah ini akan diuraikan dengan cara menguraikan 5 green sector yang telah didanai oleh sovereign green sukuk Indonesia 2018 melalui tinjauan al-kulliyah al-khamsah di atas. Pembahasan dispesifikkan kepada proyek yang didanai oleh dana sovereign green sukuk Indonesia 2018 karena laporan yang sudah dirilis tentang penggunaan dana sovereign green sukuk Indonesia hanya green sukuk 2018. Dengan hal itu, proyek 5 green sector dana sovereign green sukuk di Indonesia akan dilihat melalui tinjauan al-kulliyah al-khamsah. Di bawah ini akan menampilkan gambar yang dapat memudahkan uraian dalam studi ini. Berikut tabel tersebut: 


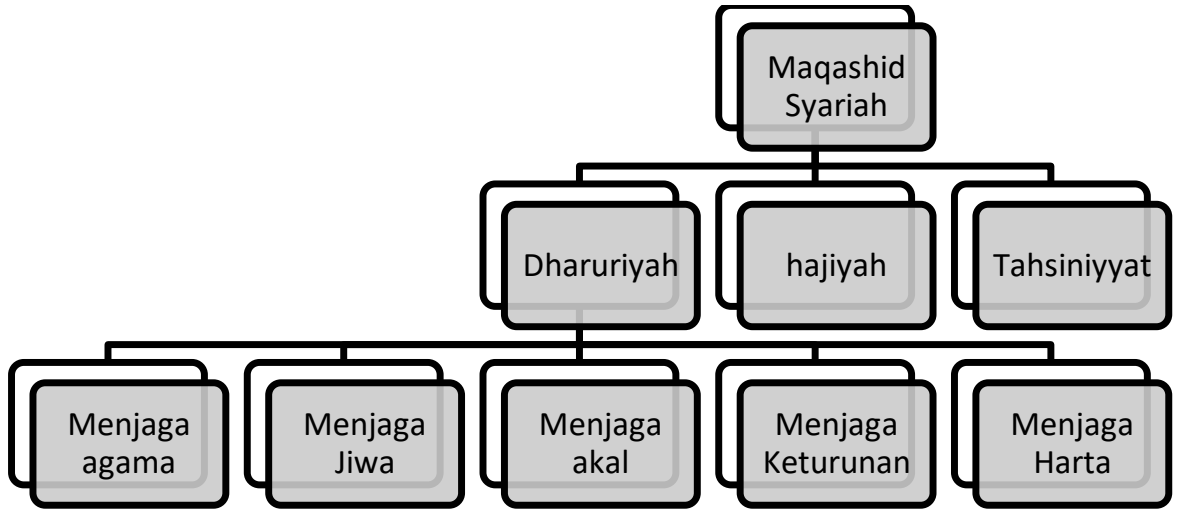

Gambar 1 . Uraian tentang Maqashid Syariah

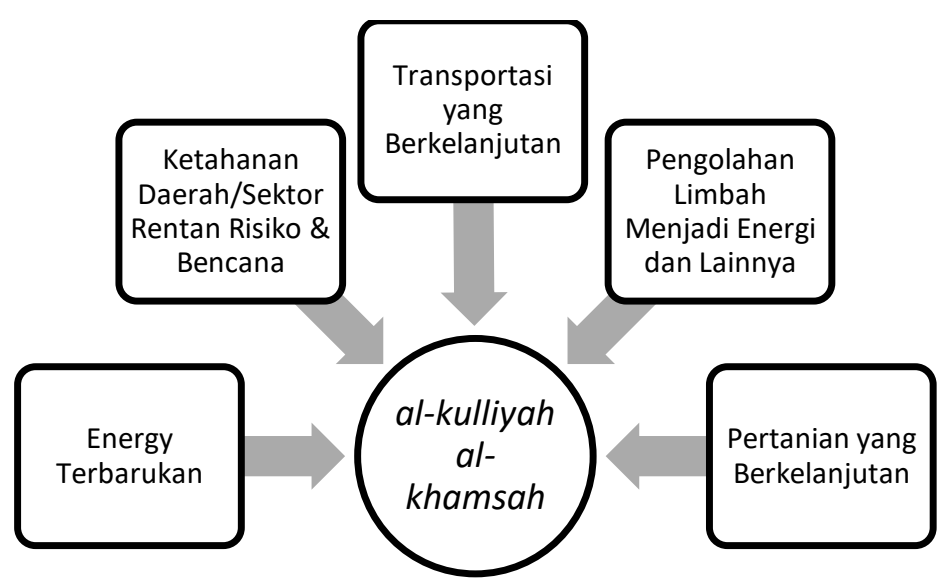

Gambar 2. Uraian Al-Kulliyah Al-Khamsah

Dalam tinjauan maqashid shariah melalui al-kulliyah al-khamsah, 5 green sector yang dibiayai oleh green sukuk Indonesia sudah sesuai dengan maqashid syariah melalui al-kulliyah al-khamsah yaitu menjaga agama (hifdzu ad din), menjaga Jiwa (hifdzu an Nafs), menjaga akal (hifdzu al aql), menjaga keturunan (hifdzu an nasl) dan menjaga harta (hifdzu al Mal). Berikut uraian masing masing dari al-kulliyah al-khamsah maqashid syariah tersebut:

\section{a. Menjaga Agama (hifdzu ad din)}

Tujuan sovereign green sukuk Indonesia adalah untuk membiayai proyek proyek yang memiliki manfaat lingkungan atau iklim yang positif (climate benefits) di wilayah Indonesia. Dana yang diperoleh dari sovereign green sukuk digunakan untuk mendanai proyek "hijau" saat ini atau di masa depan atau untuk membiayai kembali proyek "hijau" yang ada. Proyek Hijau bertujuan untuk mengatasi masalah utama yang menjadi perhatian penting yaitu perubahan iklim dan mitigasi resiko atau bencana sebagai bentuk dari komitmen untuk menjaga lingkungan (DJPPR Kemenkeu,2019).

Berdasarkan tujuan tersebut, pembahasan mengenai maqashid shariah di beberapa referensi terdahulu, memang belum ditemukan yang menyatakan bahwa penjagaan lingkungan/environment (hifz al-bi'ah) meruapakan bagian dalam dharuriyah maqashid syariah. Imam Syatibi sebagai pencetus al-kulliyah al-khamsah (5 aspek menyeluruh) tidak menyebutkan penjagaan lingkungan/environment (hifz al-bi'ah) sebagai bagian dalam maqashid syariah. Sementara itu seperti telah diketahui oleh umat islam pada umumnya bahwa menjaga lingkungan hidup merupakan perintah ajaran Islam dan tergolong bagian kajian dalam ekonomi Islam.

Penjelasan di atas berdasarkan penjelasan yang terdapat dalam kitab suci al-Qur'an, seperti yang telah ditelaah oleh ulama ahli tafsir melalui kamus untuk pencarian ayat-ayat al-Qur'an ( $\mathrm{al}-\mathrm{Mu}$ 'jam al-Mufahras li Alfaz al-Qur'an), yang menyebutkan bahwa terdapat banyak sekali ayat-ayat yang berbicara tentang kewajiban penjagaan lingkungan hidup. Pembahsan tentang bumi secara umum disebutkan dalam al-Qur'an kurang lebih ada sekitar 459 ayat, khususnya di ayat al-Baqarah: 11, 60, 
251, 22, 27, al-Mu'minun: 71, al-A'raf: 100, Ali Imron: 109, 129, 109, 129, dan lain sebagainya. Ada kesesuaian penjagaan lingkungan hidup ( hifz al-bi'ah) dengan beberapa ayat dalam al-Qur'an, terutama dalam ayat ayat yang berkaitan dengan larangan Allah untuk merusak bumi.

Berdasarkan uraian tersebut, kendati menjaga lingkungan (environment) bukan termasuk bagian dari al-kulliyah al-khamsah namun menjaga lingkungan (environment) atau hifz al-bi'ah termasuk bagian dari ajaran agama islam yang harus dijaga dan dilakukan. Dengan demikian menjaga lingkungan merupakan bagian menjaga agama (hifdzu ad din) dalam al-kulliyah al-khamsah maqashid syariah karena menjaga lingkungan adalah termasuk perintah Allah SWT yang terdapat dalam Quran seperti ayat al-Baqarah: 11, 60, 251, 22, 27 dan lainnya. Dengan begitu menjaga lingkungan adalah bagian dari menjaga ajaran ajaran agama islam yang harus di laksanakan oleh semua umat islam.

\section{b. Menjaga Jiwa, Akal dan Keturunan (hifdzu an nafs, aql, an nasl)}

Kemunculan sovereign green sukuk Indonesia dimotori oleh semangat untuk menjaga lingkungan dalam kerangka pembangunan berkelanjutan. Kehadiran sovereign green sukuk merupakan upaya untuk memperbaiki kerusakan lingkungan hidup baik factor alam maupun akibat perilaku manusia. Sebab kerusakan lingkungan ini memiliki pengaruh yang besar bagi keberlangsungan ekosistem lingkungan hidup bila dibiarkan dan terjadi secara terus menerus. Pada umumnya, kerusakan lingkungan dikarnakan kegiatan manusia yang tidak ramah pada lingkungan seperti perusakan hutan dengan cara penebangan pohon secara terus menerus dan menjadikan lahan hutan di alih fungsi kan, pertambangan, pencemaran udara melalui pemakaian ac atau asap kendaraan bahkan asap industri, pencemaran air dan tanah dan sebagainya. Kerusakan lingkungan atau krisis lingkungan ini nantinya akan menyebabkan bencana di mana-mana. Bencana banjir, tanah longsor, kebakaran hutan dan lahan, kekeringan dan lain-lain, terus terjadi. Dengan begitu, keberlangsungan masyarakat Indonesia menjadi terancam. Jiwa, akal dan populasi masyarakat indonesia yang mengalami kerusakan iklim atau lingkungan berdampak negatif kepada masyarakat Indonesia.

Oleh karenanya, keberadaan proyek hijau melalui green sukuk ini menjadi sangat penting untuk memperbaiki kerusakan lingkungan di tengah masyarakat. Semangat ini tentu demi menjaga keberlangsungan hidup makhluk di muka bumi ini dalam jangka panjang. Bila dilihat dari laporan Kementrian Keungan tentang penggunaan dana green sukuk 2018, maka bisa ditemukan bahwa proyek terbanyak adalah sector Ketahanan Daerah/Sektor Rentan Risiko \& Bencana sebanyak 241 proyek dan menghabiskan dana sebesar 7,19 triliun. Tentu jumlah proyek sovereign green sukuk terbanyak ini bertujuan untuk memitigasi resiko tentang keselamatan jiwa masyarakat Indonesia di berbagai wilayah. Sehingga semangat proyek green sector ini sesuai dengan maqashid syariah kategori menjaga jiwa, akal dan keturunan masyarakat Indonesia.

\section{c. Menjaga Harta (hifdzu al mal).}

Diantara salah satu isi Indonesia green sukuk framework yang telah direview oleh Pusat Penelitian Iklim Internasional (CICERO) adalah penerbitan laporan tentang langkah langkah pengurangan greenhouse gas emissions. Keberadaan laporan ini tentu sebagai bentuk pertanggung jawaban kepada public tentang upaya penyelamatan lingkungan melalui proyek green sector dari dana sovereign green sukuk. Kendati demikian, keharusan pelaporan ini tidak hanya sebatas laporan, tapi laporan ini sebagai bentuk pertanggung jawaban penggunaan dana dari sovereign green sukuk yang diinvestasikan oleh para investor sehingga dengan begitu rasa kepercayaan masyarakat dan investor akan semakin percaya akan pengelolaan harta. Dan pada akhirnya, keberadaan dana sovereign green sukuk memang betul betul terjaga dari penyelewengan dan penggunaan diluar sector yang telah di tentukan untuk penyelamatan lingkungan.

\section{KESIMPULAN DAN SARAN}

Green sukuk khususnya di Indonesia harus memperhatikan tujuan penerapan syariah dalam praktiknya. Tidak hanya sebatas legal dalam syariah saja, tapi harus mengakomodir maslahah dan manfaatnya untuk masyarakat Indonesia sebagai akktualisasi dari konsep maqashid shariah. Sehubungan dengan hal itu, berdasarkan laporan Kementrian Keuangan tentang sovereign green sukuk dan green sector yang dibiayai oleh dana sovereign green sukuk ditemukan fakta bahwa 5 green sector yang dibiayai oleh sovereign green sukuk Indonesia sudah sesuai dengan maqashid syariah dalam bingkai al-kulliyah al-khamsah yaitu menjaga agama (hifdzu ad din), menjaga Jiwa 
(hifdzu an Nafs), menjaga akal (hifdzu al aql), menjaga keturunan (hifdzu an nasl) dan menjaga harta (hifdzu al Mal).

Kelima green sector tersebut menjadi wujud nyata langkah pemerintah untuk menjaga lingkungan/environment (hifz al-bi'ah) di tengah perubahan iklim demi mencapai pembangunan yang berkelanjutan. Disamping itu, menjaga lingkungan adalah termasuk perintah Allah SWT yang terdapat dalam Quran seperti ayat al-Baqarah: 11, 60, 251, 22, 27 dan lainnya. Dengan begitu menjaga lingkungan adalah bagian dari mengamalkan ajaran ajaran agama islam yang harus di laksanakan oleh semua umat islam.

\section{DAFTAR REFERENSI}

Rencana Pembangunan Jangka Panjang Nasional 2005-2025 Poin IV.1.6 hal 70 "mewujudkan indonesia yang asri dan lestari" Rencana Pembangunan Jangka Menengah Nasional 20152019 bab 3 hal 16. Ditjen PPI, 2015

Direktorat Pembiayaan Syariah Direktorat Jenderal Pengelolaan Pembiayaan dan Risiko Kementerian Keuangan RI

Morea, Donato \& Poggi, Luigi Antonio (2017) "An Innovative Model for the Sustainability of Investments in the Wind Energy Sector: The Use of Green Sukuk in an Italian Case Study", International Journal of Energy Economics and Policy, ISSN; 2146-4553, 7 (2) 53-60.

Ascarya, \& Sukmana, R. (2014). "Modeling Islamic Financial Institution Performance Measurement Based on Maqashid Al-Shariah", Paper Presented at Workshop on Maqasid al-Shariah based Index of Socio-Economic Development, Yogyakarta, 26-27 June 2014

Dusuki, A.W \& Abozaid, A. (2007). A Crtical Appraisal on the Challenges od Realizing, IIUM Journal of Economics and Management, Vol.15 No.2, pp. 143-165

Abdullah, S. (2012). Risk Management via Takaful from a Perpective of Maqashid Shariah, Procedia- Social and Behavioral Sciences, Vol.65, pp.535-541

Al-Syatibi, Imam. (2018). The Master Architect of Maqashid.

Al-Yubi, M.Saad bin Ahmad bin Mas'ud, (2001). Maqashidu al-Syariah al-Islamiyah wa 'Alaqatuha bi al-Adillati al-Syariyyah, Riyadh: Daar al-Hijrah, hal 37-38

Kasri, R. A \& Ahmed, H. (2015). Assessing Socio-Economic Development based on Maqasid alShari'ah Principle: Normative Frameworks, Methods and Implementation in Indonesia, Islamic Economis Studies, Vol.23 No.1, PP.73-100

Abdul Aziz, A.F \& Mohamad, S. (2013). Fulfillment of Maqasid Al-Shariah via Takaful, MPRA Paper, pp.1-25

Sulaiman, Al-Saeed. K. (2012). Sukuk Issuence in Saudi Arabia: Recent Trends and Positive Expertation, Durham University

Razak, Sarah.S, Saiti.B, Dinc. Y. (2018). The Contracts, Structures and Pricing Mechanisms of Sukuk: A Critical Assessment, Borsa Istanbul Review

Fatwa Dewan Syariah Nasional 32/DSN-MUI/IX/2002

IFSB. (2013). Islamic Financial Services Industru Stability Report. IFSB, Kuala Lumpur: Inteligent Energy Europe (2011) Renewable Energy Policy Country Profiles. http://www.reshaping-respolicy.eu/downloads/RE Shappin_CP_final_18Jan2012.

Ismail, A.G, Possumah, B.T\& Kadil, M.N.A. (2014). Inter-generational transfer under Islamic Perpective, Humanomics, Vol.30 No.2, pp.95-121

Choudhury, M.A. (2015). Monetary and Fiscal (Spending) Complementarities to Attain Socioeconomis Sustainability, Journal of Finance and Risk Perpectives, Vol.4 No.3, pp.63-80

Al-Mubarak, T \& Osmani, N.M. (2010). Applications of Maqasid al-Shari'ah and Maslahah in Islamic Banking Practices: An Analysis Paper Presented at International Seminar on Islamic Finance in India

Al-Rahman, Jalal Al-Din Abd. (1983). Al-Masalih Al-Mursalah. Mesir: Matba'ah Al-Sa'adah, hal.12 Asy-Syatibi, Abu Ishaq. (1997). Al-Muwafaqat fi Usul Asy-Syari'ah. Beirut: Dar Al-Ma'rifah cet.3, hal.324

Moera, D \& Poggi, L.A. (2017). An Innpvative Model for the Sustainability of Investments in the Wins Energy Sector: The Use of Green Sukuk in An Italian Case Study. Journal International of Energy Economics and Policy, Vol.7, Issues.2 
Sirat, Abdul Hadi, Hilmiyah Nurul, Muhammad Hakimi Mohd Shafiai, "Al Maslahah Based Quality Management: A Theoretical Overview" American Journal of Applied Sciences 2016, 13 (3): 243.250

Laluddin, Hayatullah, Mohamad Nasran Mohammad, Zuliza Mohd Kursin, Shofian Ahmad, et al “An Analysis of Maslahah's Develompment Through al-Ghazali Pre and Post al-Ghazali Periods" International Business Management 6 (2); 187-193, 2012 ISSN: 1993-5250, Medwell Journals, 2012 